\title{
FORMATION OF A PETROCHEMICAL CLUSTER AND THE CREATION OF AN INTEGRATED PETROCHEMICAL COMPLEX IN KAZAKHSTAN
}

\author{
Assel Kadyrbergenova, ${ }^{1}$ Saule Yegemberdiyeva, ${ }^{2}$ Kulman Orazbayeva $^{3}$
}

\begin{abstract}
The problems associated with the development of the petrochemical industry of the Republic of Kazakhstan are investigated by creating a petrochemical cluster in the western oil and gas region of the country. The issues of a forming petrochemical cluster in Kazakhstan and creating an integrated petrochemical complex in Atyrau region are considered. The essence of the cluster approach as the main factor for increasing the regional competitiveness of the Atyrau region is opened, the expediency and efficiency of the creation of the petrochemical cluster and an integrated petrochemical complex is substantiated. The stages of construction of an integrated petrochemical complex are described, depending on the sources of supply of the used raw materials. An integrated scheme of the petrochemical complex was created and investment petrochemical projects in the Atyrau region were considered. The main groups of factors substantiating the opportunities for the formation of a petrochemical cluster and the achievement of an economic effect in western Kazakhstan are defined.
\end{abstract}

JEL Classification Numbers: O14 Industrialization • Manufacturing and Service Industries $\bullet$ Choice of Technology);

DOI: http://dx.doi.org/10.12955/cbup.v5.927

UDC 665.63-404(574

Keywords: petrochemical industry, petrochemical cluster, integrated petrochemical complex, special economic zone, benzene, paraxylene.

\section{Introduction}

The globalization of production and capital in a modern economy will lead to an increase in the competitiveness of goods and services. The consequence of this is the emergence of a fundamentally new economic phenomenon that has been theoretically comprehended in the concept of the cluster, which is based on the combination of individual elements into a single whole for the performance of a certain function and the realization of a specific goal. Clustering in the economy is the main factor in increasing regional competitiveness (Kuandykova, 2009).

A cluster is a group of companies that belong to one sector and operate in close proximity to each other. An industrial cluster is a series of industries that interact as a buyer-supplier or supplier-buyer, as well as through common technologies, common procurement channels or distribution of general labor associations. Regional clusters are industrial clusters, in which the participating companies are territorially close to each other. Thanks to its huge reserves of hydrocarbon raw materials, the Republic of Kazakhstan has become, in the 21st century, one of the largest exporters of oil and gas. In the action program developed by the Government of the Republic of Kazakhstan for the coming years, providing for the accelerated development of all branches and spheres of the economy, it is centered on the diversification of processing industries, including the creation and development of a petrochemical cluster, an integrated petrochemical complex in Atyrau region (Orazbayeva 2009a).

Due to the introduction of innovative developments in the real sector of the economy through the formation of a petrochemical cluster, the development of resource and energy-saving technologies, it is planned to develop high-value-added industries, accompanying and adjacent production in the oil and gas sector, and a decrease in the energy intensity of domestic production. (Bopieva, 2007; Pervushina, 2015; Braginsky, 2009). Realization of these branches can save the economy of the country from raw dependence and to produce a strong multiplicative effect within the country. For the effective solutions to these important issues, it is necessary to conduct interdisciplinary research (economy, technology, ecology, etc.) and make a scientifically-based decision.

\section{Purpose, statement of the problem.}

The aim of the work is to research opportunities of developing petrochemical productions by creating and forming a petrochemical cluster, creating an integrated petrochemical complex in Western Kazakhstan. The main tasks are (Bopieva, 2007):

\footnotetext{
${ }^{1}$ Eurasian National University, Asel-k-80@mail.ru

2 Eurasian National University, saule_8@mail.ru

${ }^{3}$ Kazakh University of Economics, kulman_o@mail.ru
} 
- studying of the problems of creating an integrated petrochemical complex in the Atyrau region;

- studying of the main indicators on resources and expected results that are available in Western Kazakhstan for the creation of a petrochemical cluster;

- justification of the feasibility and effectiveness of the establishment of a petrochemical cluster and an integrated petrochemical complex in the Atyrau region;

- studying of the stages of construction of an integrated petrochemical complex, depending on the sources of supply of the raw materials used;

- Creation of an integrated scheme of a petrochemical complex and the study of investment petrochemical projects in Western Kazakhstan.

\section{Research methods}

Let's consider the methods for solving topical tasks for the formation of a petrochemical cluster and the creation of an integrated petrochemical complex in the Atyrau area. Analysis of the effectiveness of clusters can be carried out in various directions: institutional organization of clusters; internal motivation initiation and maintenance of clusters; comparing the competitiveness of participants in a cluster; and the strategic potential of clusters. Thanks to being focused on its territory reserves of oil and gas, the Atyrau region is one of the perspectives and attractive regions of the Republic for the formation of a petrochemical cluster. Research and classification of characteristic features of clusters show their distinction in different countries, but in general, you can select the following main indicators resource and expected results that are available in the Atyrau area to create a petrochemical cluster:

- sufficient opportunities and resources researched for construction of structures in and out of the cluster and prospects for their development;

- opportunity for the development of labor-buildings and a workforce inside the enterprise's cluster;

- the proximity of suppliers of hydrocarbons and other material resources;

- the presence of equity participants cluster; - the presence of associated structure opportunities ready for joint action;

- the presence of opportunities for the intensive formation of networks - high potential for innovation and training staff.

The main purpose of the creation of a petrochemical cluster should be the development of the competitiveness of petrochemical complex Kazakhstan and its products out on the world market, increase the efficiency of its contribution to the competitiveness of the National Economy. In the Atyrau region it is possible to form a petrochemical cluster on the basis of new petrochemical objects of two companies for the production of plastics, which 50\% of shares were purchased by JSC Investigation - Production "KazMunaiGaz" on the basis of which will be created a single petrochemical complex. A cluster includes a processing company: "JSC Polypropylene," "Aktau plant plastics, JSC" Atyrau Oil Refinery "and new oil, gas processing plant under construction on Karabotan, etc. (Sarmurzina, 2007).

The proposed petrochemical cluster, provides Kazakhstan raw material, having not only the internal market, but also external markets (Iran, China, Russia), has every reason to become a real subject of the cluster development in the future.

Due to the growth of oil production in Kazakhstan, the capacity of existing GPP (Gas Processing Plant) is not enough for the full processing of gas, because it is necessary to utilize processed gas, which contains an ethane fraction from $13 \%$ to $16 \%$ and above, being a basic component of petrochemicals. The receipt of ethylene from ethane technologically and economically costbeneficially. In comparison it should be noted that the consumption of gasoline to get one ton of ethylene is 3 tons and more, while the consumption same propane for the of purpose is 1.8-2.0 tons. Further the received ethylene can be used for the production of a wide range of petrochemical products, but the most cost-benefit of Kazakhstan will release of polyethylene low and high-density, polypropylene different brands, styrene and polystyrene, ethylene glycol and benzene, methanol and the other products more than 20 items. 
The formation of clusters accelerates the process in individual industries, leading to a splash in innovation and strengthens the ability to compete in the world market (Espaev and Kireyeva, 2013). Moreover, integration into a cluster based on vertical integration will not form a spontaneous concentration of various technological inventions, but a certain system of dissemination of new knowledge and technologies (Zhekeev et al., 2007). At the same time, the most important condition for effective transformation of inventions into innovation, and innovation in competitive advantages, is the formation of a network of sustainable links between all cluster participants.

Kazakhstan is located in the center of the Eurasian continent and has no direct access to the markets for petrochemical products. In this regard, the transport component in the cost of petrochemical ready products, taking into account the indicators for transportation of raw materials inside the Republic, will have tangible indicators for its increase. Taking into account these facts, as well as ensuring the breakthrough development of the petrochemical industry for the economic niche in the international market for petrochemical products, the Ministry of Energy and Mineral Resources of the Republic of Kazakhstan, in conjunction with JSC NC "KazMunaiGaz", is implementing a set of measures to create favourable economic conditions through the formation of a special economic zone (SEZ) (Sarmurzina, 2007). The terms and status of the SEZ will ensure the release of enterprises that are part of investors and executors of the construction sites of petrochemical complexes of SEZ, from customs duties on imported licensed technologies, equipment and materials, exemption from payment of corporate tax, land tax, VAT and other mandatory payments in the budget.

\section{Results and discussion}

Based on the analysis of the prerequisites and conditions for the development of the economy of the western region of Kazakhstan, the petrochemical industry is defined as the main competitive industry, for development of which it is necessary to direct domestic and foreign scientific potential, which will allow to raise innovative entrepreneurship to a new level. The development strategy for the Atyrau region has defined the need for creating facilities for deep processing of oil and gas for obtaining a wide range of science-intensive products with 5-6 redistribution, restoration and development of the petrochemical industry (Orazbayeva, 2008). Currently, in this priority area with the involvement of petrochemical specialists, proposals have been developed on the composition and structure of the regional petrochemical cluster. Within the realization of this cluster, the implementation of modern technologies for deep processing of hydrocarbon raw materials produced in the region is being implemented with the acquisition of science-intensive petrochemical products. (Serikov and Orazbayeva, 2009; Orazbayeva et al., 2013; Orazbayev et al., 2013; Orazbayev et al., 2014).

Step-by-step construction of an integrated petrochemical complex will be carried out in the areas of Karabatan, Kulsary and Atyrau stations, depending on the sources of supply of the used raw material:

Step-by-step construction of an integrated petrochemical complex will be carried out in the area of Karabatan, Kulsary and Atyrau stations, depending on the sources of supply of the used raw material: Construction of the polypropylene Complex is the first step to create a petrochemical cluster in the region followed by obtaining high-basic products of the industry.

The Project provides to use worldwide high technology on deep processing of the propane (Phase 1) and ethane (Phase 2) to obtain the following types of commercial product: polypropylene - 500000 tons per year.

As a result of the project it is expected to create 30000 jobs and produces more than 3000 types of final outputs within Technopark located in the Special Economic Zone in West Kazakhstan, development of small and medium business, expansion of the tax base, and development of related industries.

At present, the concept of its formation and construction of an integrated petrochemical complex in the industrial zones Karabatan, Kulsary and in the Tengiz area (optimal points for the umbrella principle for fractionation and deep processing of raw materials) has been developed in the Atyrau region to create the SEZ "National Industrial Petrochemical Science and Technology Park." (Orazbayeva, 2009b; Orazbayeva, 2009c).

The goal of the project is the creation in Kazakhstan of petrochemical industries for deep processing of domestic hydrocarbon raw materials (oil and gas) and the release of basic and high added value petrochemical products. 
Most of the activities of the first stage of the Program have been completed, the number and list of petrochemical complexes that are economically profitable in Kazakhstan have been determined. Specific indicators on the parameters of petrochemical complexes, sources and volumes of the necessary hydrocarbon raw materials have been obtained to ensure their uninterrupted processing. Natural and associated gases will be used in which the fraction containing ethane is between $13 \%$ and $16 \%$ or more of the total volume of gas, which is the main economic and technological advantage for the production of ethylene, the basic petrochemical product. Further, the ethylene produced can be used to produce a wide range of petrochemical products, but the most economically profitable for the Republic will be the production of low and high-density polyethylene, polypropylene of various grades, styrene and polystyrene, ethylene glycol and benzene, methanol and other products of more than 20 titles.

To create various petrochemical industries in Kazakhstan, it is necessary to create a product for the production of basic petrochemical products - an integrated petrochemical complex (Figure 1).

The creation of a domestic base of raw materials for petrochemical industries based on the abovementioned deposits is based on the implementation of investment projects presented in Table 1.

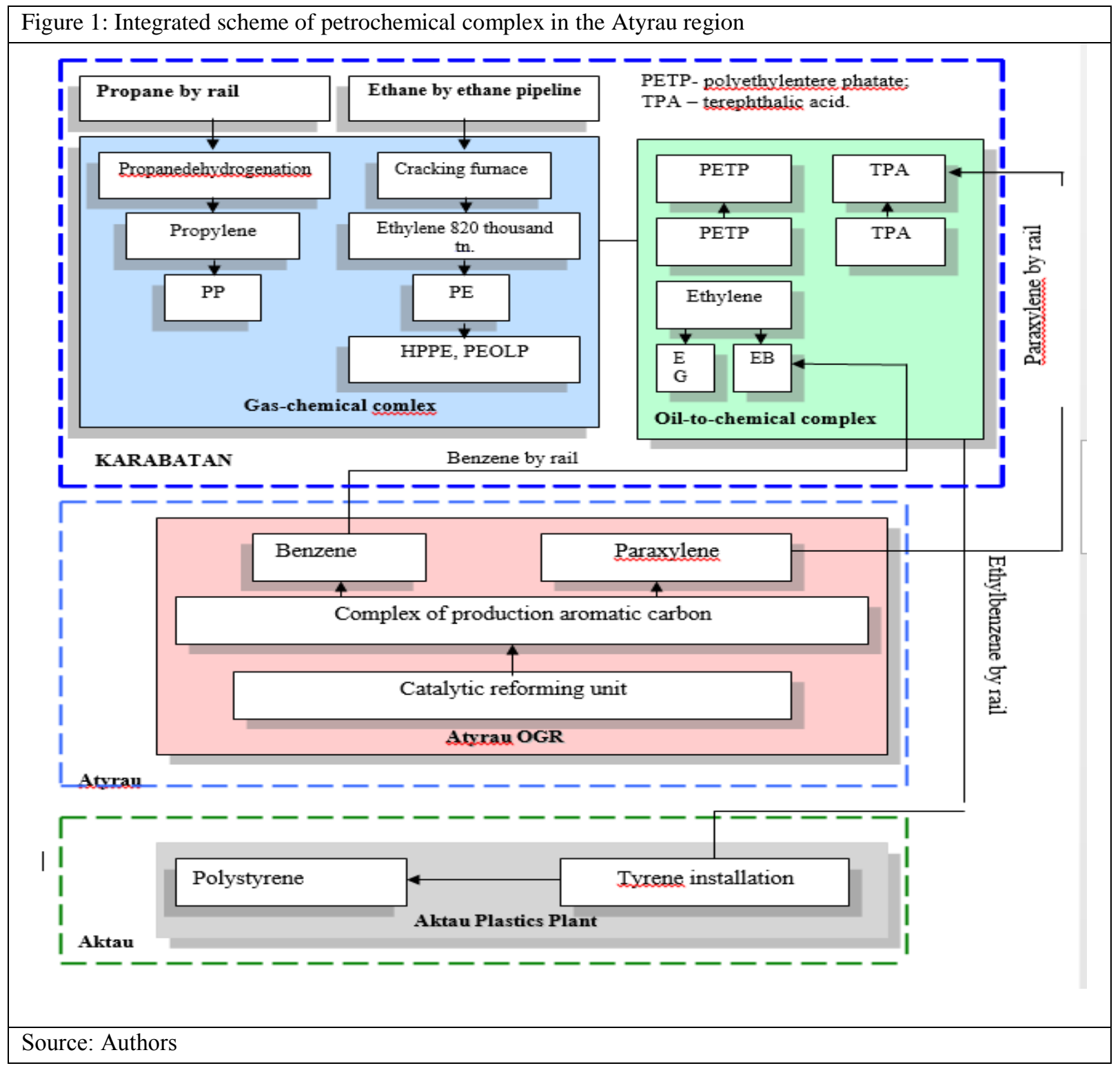

Thus, in Kazakhstan, when implementing investment projects, it is planned to create real sources of raw materials for the petrochemical industry, which, through a chain of added value, will produce a wide range of petrochemical products. 


\begin{tabular}{|l|l|l|l|}
\hline \multicolumn{2}{|l|}{ Table 1: Investment petrochemical projects in Atyrau region. } \\
\hline $\begin{array}{l}\text { Project name chemical complex in the Atyrau } \\
\text { region }\end{array}$ & Raw material & Product \\
\hline $\begin{array}{l}\text { Aromatic hydrocarbons production } \\
\text { complex in the Atyrau Oil refinery }\end{array}$ & $\begin{array}{l}\text { Gasoline fractions of } \\
\text { the Atyrau refinery }\end{array}$ & $\begin{array}{l}\text { Polyethylene } \\
\text { Polypropylene }\end{array}$ \\
\hline $\begin{array}{l}\text { Petrochemical complex based on ben- } \\
\text { zene and paraxylene }\end{array}$ & $\begin{array}{l}\text { Benzene } \\
\text { Paraxylene }\end{array}$ & $\begin{array}{l}\text { Ethylbenzene } \\
\text { Ethylene glycol } \\
\text { PET (polyethylene tereph- } \\
\text { thalate-lat) }\end{array}$ \\
\hline $\begin{array}{l}\text { Diversification of the Aktau plant of } \\
\text { plastics }\end{array}$ & Ethylbenzene & Polystyrene \\
\hline
\end{tabular}

Source: Authors

The cost of production for complex processing of oil will be low, which will allow a fierce struggle in the market for the sale of petroleum products. The existing petrochemical enterprises in Kazakhstan cannot withstand competition. Therefore, it is necessary to create a scientific concept for reforming the petrochemical industry in Kazakhstan. It is necessary to focus on the world's advanced enterprises. (Braginsky, 2003; Qing, 2007; Alfadala et al., 2009; Buzurtanova and Smirnova, 2010; World Intellectual Property Organization, WIP, 2011; Abu Dhabi UAE Petrochemical cluster, 2012; Dyrdonova, 2013; Melnik and Dyrdonova, 2014)

At present, there is no hydrogen production in Kazakhstan, and it is needed in large quantities for existing hydrotreatment processes, as well as future processes of hydrocracking, alkylation and others. Olefins (ethylene, propylene, butylene and isobutylene) can be used directly as a monomeric feedstock for petrochemistry. The absence of any of the above processes will lead to costs for the economy and ultimately will affect the cost of production. When processing oil according to the scheme of atmospheric distillation, existing in Kazakhstan, from each ton, the output is about $\$ 880$. If all processing processes are implemented, all petrochemical syntheses that exist in the petrochemical complex, then about 2,2 thousand dollars of oil will be received from a ton of oil.

At the same time, fuel oil is mainly used as fuel at the CHP (combined heat and power) although it extracts the most expensive petroleum products, for example, lubricating oils, which are not produced in Kazakhstan. From this part of the oil, tar is obtained - raw materials for the production of bitumen, which is so much needed today for road construction, which is declared one of the government's priorities in the country. When burning fuel oil together with it, metals (vanadium, nickel, cobalt) contained in Kazakh oil and concentrated in heavy fractions are completely lost. If we add sulphur here, the content of which in fuel oil reaches $2 \%$, and which is selected into the atmosphere in the form of sulphur dioxide, turning into acid rains, the advantages of burning fuel oil turn into negatives. In Kazakhstan, the entire gas part of oil and gas raw materials is not processed. At best, the gas is supplied to the furnace, and in most cases, it is flared. At the same time, in addition to hydrocarbons, associated gas of oil production contains hydrogen sulphide and its incineration without purification is unacceptable.

It follows from the above that it is criminal negligence, which leads not only to the loss of additional cash receipts, but also creates unsolvable environmental problems to continue processing oil under a truncated scheme, without seeking the complex use of raw materials.

\section{Conclusion}

As a result of research into the formation of the petrochemical cluster in Kazakhstan, it is determined that there are numerous objective and subjective prerequisites for the accelerated creation and development of this cluster available in the Atyrau region. It is possible to single out the following 
groups of factors that justify the possibilities for forming a petrochemical cluster and achieving an economic effect.

The first group of factors is conditioned by the interconnection of potential resource and technological preconditions: for the petrochemical industry, Kazakhstan's heavy paraffin sulphurous oil is the best source of raw material; It is necessary to consider the technological interconnectedness of the petrochemical cluster; creation of new production facilities taking into account the existing infrastructure for the extraction and processing of hydrocarbon raw materials. All of the above will allow to help lay the foundation for the development of the petrochemical industry along the chain of subsequent complications of production to increase added value in the final product.

The second group of factors is predetermined by the reasons for the world demand for products and the need to provide an equivalent exchange in the international division of labor. Kazakhstan has large enterprises for the production of petrochemical products, which has a huge world demand. The demand for petrochemical products of the international market shows that the creation of basic petrochemical production facilities for the production of polyethylene, polypropylene, styrene and polystyrene, ethylene glycol and benzene will be very economically profitable for Kazakhstan.

The third group of factors is due to the possibility of activating the resumption of activities of petrochemical enterprises.

The fourth group of factors is predetermined by incentive motives to ensure high profitability of industries. The presence of an own hydrocarbon based requires the formation of a petrochemical complex that ensures deep processing of raw materials into final high-tech and science-intensive products to saturate the domestic market instead of imports and to expand the export potential of the final product.

The fifth group of factors is predetermined by the strategic platform for diversifying the country's economy in connection with the entry into the category of highly competitive countries. This dictates the expediency of forming a cycle of production of final products, which is the basis for creating a petrochemical cluster in the Republic of Kazakhstan. The development of an innovative cluster of petrochemicals can be a decisive factor in accelerating the diversification of the economy, promoting the activation of non-resource, high technology and high-tech industries.

The conclusion from the above is that the development of the production of petrochemical products in the Republic of Kazakhstan should become a priority not just as one of the fashionable strategies that will be forgotten immediately after the emergence, but as a plan for the development of one of the most important and strategic industries. Implementation of the cluster strategy and competitiveness of the economy can be facilitated by government policy aimed at solving the problem of transition from the import substitution stage to the stage of large-scale investments in the petrochemical industry and the creation of a petrochemical cluster. In the strategy for the development of the national economy of the Republic of Kazakhstan, it is necessary to add some changes, the basis of which should be based on the creation of a large petrochemical production, the source of raw materials should be oil, natural and associated gases extracted from the currently exploited deposits and concentrated on promising areas.

\section{References}

Abu Dhabi UAE Petrochemical cluster (2012). Microeconomics of Competitiveness: Firms Clusters and economic development. Harvard Business School.

Alfadala H.E., Reklaitis G.V. R., El-Halwagi M.M. (Editors) (2009) Proceedings of the 1st Annual Gas Processing Symposium, Volume 1: January, 2009 - Qatar (1st ed.). Elsevier Science. (402-414) ISBN 0-444-53292-7

Bopieva, Zh. K. (2007). Strategic planning of territorial development: the forecast of development of the Atyrau region for the period till 2015. Astana, EFI magazine, 2(6), (65-67), Retrieved from// www.economy.kz

Braginsky O.B. (2003) World petrochemical industry. Мировая нефтехимическая промышленность. Moscow: Nauka, page 556

Braginsky O.B. (2009) Petrochemical complex of the world. Нефтехимический комплекс мира. Moscow: Academia, (799)

Buzurtanova E.S, Smirnova V.A. (2010) Problems and prospects of petrochemical clusters formations in Russia. Journal of Oil, Gas, Business, №11, (13-25)

Dyrdonova A.N. (2013) Clustering of the petrochemical industry of the Republic of Tatarstan. Кластеризация нефтехимической отрасли Республики Татарстан Bulletin of Kazan Technological University. Tom: 16, №12, (221-224) 
Espaev S.S., Kireyeva A.A. (2013) Concept for formation and development of prospective national clusters. Almaty, Ministry of Education and Science PK. Scientific committee. Institute of Economics. (234)

Kuandykova A.A. (2009) Efficiency of cluster formations in the Republic of Kazakhstan (using the example of petrochemistry). Эффективность кластерных образований в Республике Казахстан (на примере нефтехимии). The dissertation author's abstract on competition of the scientific degree of the candidate of economic sciences. -Almaty, (29 page).

Melnik A.N., Dyrdonova A.N. (2014) Infrastructural support for development of the territorial petrochemical cluster // Mediterranean Journal of Social Sciences. Vol.5, № 18, (299-304)

Orazbayev B., Kurmangaziyeva L., Orazbayeva K., Utenova B. (2013) Formultion and Solving the Problem of the Fuzzy Mathematical Programming to Optimize the Operation Oil Equipment Plant//Word Applied Sciences Journal 15(1): ISSN 1818-4952, Htpp://www.idoci.org/wasj/wasj28\%2812\%292913.htm.

Orazbayev B,. Orazbayeva K., Utenova, B. (2014) Development of Mathematical Models and Modeling of Chemical Engineering Systems under Uncertainty // Theoretical Foundation of Chemical Engineering // ISSN 0040-5795. Vol. 48, № 2, (138-147)

Orazbayeva K.N. (2008) Problems of the feasibility study of the production of benzene at the Atyrau refinery. Проблемы технико-экономического обоснования производства бензола на Атырауском НПЗ// Bulletin of Atyrau Oil and Gas Institute, No. 3 (15), (210-219)

Orazbayeva K.N. (2009a) Prospect and efficiency of creating a petrochemical cluster in the Atyrau region. Перспектива и эффективность создания нефтехимического кластера в Атырауской области//7-international scientific conference "Scientific and technological development of the oil and gas complex". -Almaty, (399-404)

Orazbayeva K.N. (2009b) The project for the construction of an integrated petrochemical complex in Kazakhstan. Проект строительства интегрированного нефтехимического комплекса в Казахстане//Materials of the IV ISC "Strategic Aspects of Innovative Development of National Economies of the CIS Countries in the Conditions of the World Financial Crisis". Aktobe, (136-138)

Orazbayeva K.N. (2009c) Problems of development and creation of a petrochemical complex in Kazakhstan//Science and education of Southern Kazakhstan. Republican scientific journal. №6 (79), (114-117).

Orazbayeva K.N., Utenova B, Orazbayev B. (2013) Project for the creation of an integrated petrochemical complex in the Atyrau oblast. Атырау облысында интегрленген мұнай химиясы кешенін салу жобасы [Проек создания интегрированного нефтехимического комплекса в Атырауской области].// Materials of the ISPC "Ecology and oil and gas complex" -Atyrau: AIOG, (613-619)

Pervushina A.S. (2015) Foreign experience in the development of petrochemical clusters. Зарубежный опыт развития нефтехимических кластеров. Bulletin of the Samara State Economic University. 2015. №1, (42-47)

Qing, Z. B. H. (2007) Study of Problems and Solutions of Fujian Petrochemical Industrial Cluster. Proceedings of the 5th International Symposium on Management of Technology, (1565-1568)

Sarmurzina R.G. (2007) Petrochemical production in Kazakhstan. Нефтехимические производства в Казахстане // Journal of Oil and Gas. 2007. № 3, 104-107.

Serikov F.T, Orazbayeva K.N. (2009) Mathematical formalization of the problem of optimization of petrochemical objects, problems and approaches to their solutions. Математическая формализация задачи оптимизации нефтехимических объектов, проблемы и подходы к их

решеням // Scientific journal of the Ministry of Education and Science of the Republic of Kazakhstan "Search", №3, (199204)

World Intellectual Property Organization (WIP, 2011), World Intellectual Property Indicators, http://www.wipo.int/ipstats/en/

Zhekeev A.M, Orazbayeva K.N, Serikov F.T, Orazbaev B.B. (2007) The state and prospects of the development of science and innovation infrastructure in the Atyrau region. Состояние и перспективы развития науки и инновационной инфраструктуры в Атырауской области. Journal of Contemporary Scientific Herald. Belgorod: №1 1, (18-25) 